\title{
ACRL preconferences in Miami Beach
}

\section{Miami preconferences cover rare books, active learning, and the Net}

CRL will offer four preconferences prior to the ALA Annual Conference in Miami Beach this summer. Details about each follow.

\section{5th rare books preconference}

"From Collector to Donor: Building Special Collections with Private Passions" is the theme of the Thirty-fifth Preconference of the Rare Books and Manuscripts Section of ACRL, to be held in Miami Beach, June 21-24, 1994. The history of special collections is in large part a history of private collections that have passed to public institutions, whether by gift, bequest, or purchase. The program sessions will examine how librarians and collectors interact, looking both to the past and to the future.

The range of discussion will include consideration of such issues as the expectations and needs of collectors, the role of planned giving within a library's development policy, problems encountered with donor restrictions, the role of the book and manuscript seller in placing a collection with an institution, and legal problems related to agreements with donors and their estates.

Speakers. T. Kimball Brooker, collector: "Private Collectors and Public Libraries"; Lynda Claassen, University of California, San Diego: "The View from Special Collections"; Paul F. Helfer, collector: "Divesting Donors of Their Donations: The 1993 Tax Act As Friend of the Library"; Marie E. Korey, Massey College, University of Toronto: "To the Cause of Bibliomania Throughout the World: The Role of Book Collecting Societies"; Ronald Lieberman, The Family Album: "The Role of the Book and Manuscript Seller and the Nourishment of Collectors and Collections"; Rutb and Marvin Sackner, collectors: "Private Collection, Public Vision: The Ruth and Marvin Sackner Archive of Con- crete and Visual Poetry"; Elinor Des Verney Sinnette, Washington, D.C., Artbur A. Schomburg, collector, and Samuel A. Streit, Brown University: "Banquo's Ghost: Or, Living with Donor Restriction from an Earlier Time."

Seminars. Opportunities for continuing education and professional development will include a variety of seminars for preconference participants. Topics include: navigating the Internet; exhibition catalog production; the RLG Digital Image Access Project and the Berkeley Finding Aid Project; provenance and provenance files; collecting Latin American material; guidelines for security of collections; an historical view of the techniques and applications of describing rare materials; introduction to the AMC format; administering student presses; and others.

Tours. On Thursday afternoon, June 23, there will be a walking tour of the Art Deco District and tours of local libraries, both public and private. Tours include: the Arts and Cultural Plaza; the Bascom Palmer Eye Institute and the University of Miami Calder Medical Library; the Kislak Collection of Pre-Columbian Art and Rare Book Gallery; the Ruth and Marvin Sackner Archive of Concrete and Visual Poetry; the Archives and Special Collections at the University of Miami's Richter Library; Vizcaya; and the Wolfsonian Foundation.

Registration. Registration is limited to the first 250 applicants. The registration fee of $\$ 150$ for members, or $\$ 200$ for nonmembers, must be included with the registration form. This fee includes: entry to all preconference receptions, luncheons, and coffee breaks; entrance to all preconference papers and seminars; and transportation to and from the Historical Museum of Southern Florida on Tuesday evening and the Bass Museum of Art on Wednesday evening. A separate fee of $\$ 10$ will be charged for the tours on Thursday afternoon. The registration form must be received at the ACRL office by May 15, 1994. Written cancellations will be honored until May 30,1994, and are subject to 
a $\$ 50$ cancellation fee. Cancellations will be processed after the preconference. Late registration will be accepted on a space-available basis after May 15, 1994, at an additional cost of $\$ 40$ per person. For more information write: RBMS Preconference, ALA/ACRL, 50 East Huron St., Chicago, IL 60611 or call the ACRL office toll-free at (800) 545-2433, ext. 2522 or 3248.

Preconference Airline Reservations. Delta Air Lines, Inc., is the official airline of the RBMS Preconference. Conference attendees travelling roundtrip to Miami from within the United States or Canada on Delta, between June 18 and 27 , will receive a 5\% discount off their "Super Saver Fare" or 10\% off regular coach fare. Reservations must be made directly with Delta by calling (800) 241-6760, 8:00 a.m.-11:00 p.m. (EST), daily. When making a reservation please identify yourself as attending the Rare Books and Manuscripts Annual Meeting.

Preconference Hotel. The Doral Ocean Beach Resort in Miami Beach is the official preconference hotel. The hotel is located at 4833 Collins Avenue in the heart of the fabled hotel district of Miami Beach. The recently remodeled 18-story tower overlooks both the Atlantic Ocean and the Intercoastal Waterway and has its own 300-foot-wide sandy beach on the ocean side. The hotel offers a number of amenities including restaurants, shops, a pool, and an aquasports center, and access to the Doral Resort and Country Club and the Doral Saturnia International Spa Resort with complimentary transportation. The Doral is a short ride from the Art Deco District and South Beach. A special conference rate has been arranged for RBMS attendees. Reservations must be made using the housing form which will be sent to you upon receipt of your registration. The cost of

\section{ADA materials sought}

The Americans with Disabilities Act (ADA) Assembly of ASCLA would like to develop a collection of transition plans and other documents related to libraries' compliance with the ADA. If your library, or its governing entity, has prepared planning or policy documents for ADA compliance that are appropriate for sharing with other libraries, please send copies to Kathleen Mayo, Chair, ADA Assembly, Lee County Library System, 2050 Lee St., Ft. Myers, FL 33901. hotel accommodations is not included in the preconference registration fee. Rates are $\$ 115$ for single or double (plus tax and service charge) with a $\$ 30$ additional charge made for a third person. Children under 18 are free if an additional bed is not required. The deadline for hotel registration is May 21, 1994.

\section{Active learning in libraries}

"Integrating Active Leaming into Library Instruction: Practical Information for Immediate Use" is the preconference being offered by ACRL's Bibliographic Instruction Section, 8:30 a.m.-4:30 p.m., Friday, June 24. Lunch will be included.

Join the nationwide movement in higher education to improve the quality of teaching. Active learning is a topic generating widespread interest and enthusiasm. This is your opportunity to explore active leaming from both a theoretical and a practical perspective.

Audience. This preconference is aimed at librarians interested in providing effective instruction for their library users.

Speakers. The preconference begins with keynote speaker Trish Ridgeway, the Handley Library, presenting "Active Learning in Library Instruction: Why to Do It and How to Do It." Then you move into small group sessions which involve you in active learning experiences. You can readily apply these experiences to your current and future instruction activities. The other presenters are: Suzanne Byron and Greg Sidberry, University of North Texas, "Cooperative Learning and Library Instruction: Practical Applications"; Sbirley Cody, Grand Valley State University, "A Demonstration of Cerise Oberman's Question Analysis Learning Cycle"; Ross T. LaBaugh, University of Massachusetts at Dartmouth, "Not Another Tour of the Library: Using Your Head (Instead of Your Feet) to Learn the Library"; Carol Reed, University of Toledo, "Innovation in Teaching Library Usage: Flowcharting the Research Process."

Registration. The registration fee is $\$ 150$ for ACRL members, $\$ 185$ for ALA members, and $\$ 215$ for non-ALA members. The deadline for registration is May 17, 1994.

\section{Internet tools and services}

"Navigating the Internet: Tools, Services, and Issues" will be cosponsored by ACRL and the Coalition for Networked Information and held 9:00 a.m-5:00 p.m., Friday, June 24. Lunch will be included. 
Attending this preconference will enable you to: define and compare major Internet navigational tools and describe specific uses; describe a range of services you could provide (both as information providers and in support of users) using Internet resources; describe issues for acquiring and cataloging Internet resources; and define policy areas related to the Internet and the services that you offer.

Audience. Attendees should have basic knowledge of the Internet and have had basic experience using it (e-mail use only is okay).

Speakers. The speakers include Paul Evan Peters and Joan Lippincott, Coalition for Networked Information; Laura Kelleber, Merit Network; plus practicing librarians who are expert Internet users.

Registration. The registration fee is $\$ 150$ for ACRL members, $\$ 185$ for ALA members, and $\$ 215$ for non-ALA members. The deadline for registration is May 17, 1994.

\section{Conference proceedings}

"Bibliographic Control of Conference Proceedings" is an ACRL/ALCTS joint preconference to be held 9:00 a.m. $-4: 30$ p.m., Friday, June 24 .

Audience. The preconference is for professionals, paraprofessional staff, and students involved with or interested in cataloging, public services, or collection development aspects of conference proceedings.

Speakers. Nationally recognized librarians in the field of cataloging, public services, and collection development will discuss the many issues and concerns related to the bibliographic control, access, and acquiring of conference proceedings. Representatives from major publishers of conference proceedings will also present the issues confronting the publishing industry.

Registration. The registration fee is $\$ 95$ for ACRL members, $\$ 145$ for ALA members, and $\$ 185$ for non-ALA members. The registration deadline is May 17, 1994.

\section{ACRL preconference registrotion form}

Deadline: May 17, 1994

Note: Please call the ACRL office to request a form for the RBMS preconference.

Please type or print:

Name (as it should appear on your badge)

Title

Organizational Name (as it should appear on badge)

Mailing Address

City State/Zip

Telephone (daytime) Fax

AL.A Membership Number

Send registration form with payment to:

ACRL Preconferences

50 E. Huron St.

Chicago, IL 60611

Or fax registration and charge information to: ACRL Preconferences: (312) 280-2520
Select a preconference and circle the fee

\begin{tabular}{lccc} 
Preconference & $\begin{array}{c}\text { ACRL } \\
\text { member }\end{array}$ & $\begin{array}{c}\text { ALA } \\
\text { mem. }\end{array}$ & $\begin{array}{c}\text { non- } \\
\text { ALA } \\
\text { mem. }\end{array}$ \\
\hline $\begin{array}{l}\text { Integrating Active } \\
\text { Learning }\end{array}$ & $\$ 150$ & $\$ 185$ & $\$ 215$ \\
$\begin{array}{l}\text { Navigating the } \\
\begin{array}{l}\text { Internet } \\
\text { Bibliographic }\end{array}\end{array}$ & $\$ 150$ & $\$ 185$ & $\$ 215$ \\
$\begin{array}{l}\text { Control } \\
\text { Nont }\end{array}$ & $\$ 95$ & $\$ 145$ & $\$ 185$
\end{tabular}

\$35 late fee after May 17, 1994

Total payment: Check enclosed: $\square$

or Charge: $\square$ Visa $\square$ MasterCard $\square$ AmEx

Expiration Date

Card Number

Signature

Written cancellations will be honored until June 5, subject to a $\$ 45$ cancellation fee. 